\title{
When Death Comes Knocking
}

Ed Bowser

T ike it or not, death is a sad but inevitable fact of life for all human beings. Although death is an unpleasant subject, it is unavoidable. Not only do we all face the certainty of dying, but we also will be forced to deal with the loss of someone we know, love, or care about on the journey to our own eternal sleep.

In August, 2004 I experienced the loss of my mother. At the age of 68, she finally succumbed to the ravages of a deadly form of cancer. By virtue of my incarceration, I was spared the pain of watching my mother die a slow and painful death. My siblings were not so fortunate. We all knew that Mom's death was inevitable. The only question was when it would come.

Under the best of circumstances, dealing with the loss of a friend or loved one can be difficult. Dealing with such a loss while in prison can be particularly lonely and isolating.

In society, the news of the death of a loved one is generally delivered in a compassionate and caring manner by someone known to us or by a caring professional experienced in delivering difficult news. Friends and family members are frequently there to offer consolation and support to one another and share in the grieving process. In sharp contrast, a prisoner is completely alone and will likely learn of the death of a friend or family member through a staff member assigned to deliver the news. Or, as in my case, a staff member will inform a prisoner to call home. The message to "call home" in and of itself is enough to send a shiver down the spine of the most stoic of prisoners. Prisoners are acutely aware of the fact that messages to call home are only delivered in the most grave of circumstances.

Receiving the news of a death while in prison is difficult enough. The fact that a prisoner has no access to friends and loved ones for support and consolation makes it even more difficult. Fellow prisoners are sympathetic but incapable of sharing the experience or replicating the support and consolation one receives from family and friends in difficult times.

Clearly, people grieve differently. For me, the inability to be with those I love only emphasized my loss. I felt an up swell of emotion over the loss of my mother as the realization set in that I would never see her again; she would never see me as a free man. Department of Correction (DOC) policy would forbid me from attending any ceremony or service as my mother had lived in Rhode Island.

As I received the news of my Mom's passing from my sister, I saw a Lieutenant enter the housing unit. After a brief exchange with the housing 
officer, the Lieutenant peered down to where I was speaking on the phone. I knew instantly that the Lieutenant was waiting to see me. I began to feel anxious. I reminded my sister that I had asked everyone in my family not to call the institution in the event of my mother's death as I anticipated the possibility of staff inserting themselves into what I believed to be a private matter. My sister took umbrage with this. As I observed the Lieutenant periodically peering at me, my anxiety grew and the call deteriorated to the point where I told my sister that I had to go to see what hoops I was going to be forced to jump through.

I hung up the phone and attempted to go directly to my cell. The Lieutenant intercepted me. He asked how I was doing. I said, "Okay, but I want to go to my cell to be alone." The Lieutenant then informed me that I had to go to the Health Services Unit (HSU) to "speak with someone". I tried to explain to the Lieutenant that I was fine and wanted to deal with my loss privately. I was then told that I did not have a choice - that it was "protocol". The last thing I wanted was to be compelled to speak to a stranger about my loss.

With my emotions ping-ponging from sadness to anger at this unnecessary intrusion, I realized that my loss and my needs meant nothing. I was being forced to speak to someone for the benefit of the MCI-Norfolk prison administration and the DOC. The clear intent of the "protocol" was to relieve the prison administration and the DOC of any liability if a prisoner were to act out over learning the news of such a loss. This was not an attempt to console or comfort a prisoner.

I decided that it might be better to accompany the Lieutenant to the HSU than to be placed in the segregation unit for failing to comply. As the Lieutenant escorted me to the HSU, my feelings of sadness and anger were exacerbated by the knowledge that bringing me to speak with someone was not for my benefit but rather for liability purposes. They were playing a game of cover your ass and I was the game piece.

Once in the HSU, I was delivered into the custody of a nurse whose primary responsibility was dispensing medication. She had me sit down and began to tell me that she was sorry to hear of my loss. I remained quiet. Normally this sympathetic expression would have been appreciated. In this context, it was offensive. She then asked, "Is there anything I can do to help?" I said, "Yes, despite my many years in prison, I have developed perfectly good coping skills and I would like to be left alone to go back to my cell and grieve in private." 
I am sure to the nurse I seemed aloof or even angry. By this time, I was mostly offended and put out by the continuing intrusion. I had expressed what I needed in as clear a manner as possible and yet the nurse persisted. I anticipated the words she was about to speak before they were completely off her lips. She said, "Well, before I can let you go, I'm going to have to ask you to ...". I interjected by saying, "Please don't insult me by asking me to contract for safety." She said, "Well, until you do, I can't let you go." At that point, I had had my fill of this charade and was no longer willing to play along. I said, "Fine, then you call the Lieutenant and have me locked up because I am not contracting with you or anyone else for anything. I just lost my mother. I have asked to be left alone to grieve privately, and no one seems to respect my needs or wishes. So you go ahead and have the Lieutenant place me in segregation and you can go home tonight and tell your friends and family how you helped a prisoner today - by having him placed in segregation for wanting to grieve his mother's death in private. Now with all due respect, I have nothing more to say to you or anyone else."

The silence in the room was long and deafening. I viewed the nurse as just another in a long line of good soldiers - doing her part to protect the DOC. As I sat there in silence I began to feel as though the only way I would finally be alone to grieve would be if I were in segregation. I regretted not taking that as my first option when the Lieutenant informed me I had no choice.

Thankfully, the nurse said, "Okay, you can go back to your unit." I breathed a sigh of relief as I headed for the door.

Once in my unit I fell back on my bunk where I was finally able to let myself feel the loss of my mother. Alternate feelings of sadness and joy washed over me. I was sad for the loss of my mother, but grateful for the end of her suffering. Because of her illness, I had not seen my mother for several years. I missed her before, but now the finality of her death made me miss her like never before. I yearned to see her one more time and to be surrounded by my siblings and loved ones whom I knew were feeling what I felt. In that moment, with tears streaming down my cheeks, I could hear my mother's faint and frail voice during a recent phone call saying, "I just want to live long enough to see you come home." I knew it was not to be.

At the age of 46, I was experiencing the same sense of being alone that I had felt nearly 30 years earlier when the big steel door closed behind me 
as I entered the state prison. Mom was gone. There would be no "home" to return to.

The point of all of this is that prisoners do not cease to be thinking, feeling, caring human beings when the door closes behind them. Despite the fact that we are often treated like cattle, we feel like any other human being. The majority of us have the ability to express our needs and act appropriately, even in the most trying of situations. Security concerns about prisoners should not result in one size fits all policies and protocols that trump our needs as human beings. A more humane and compassionate protocol would likely do more to assure safety and security than that currently employed. A less stable and more reactionary prisoner may well have acted out as a result of the intrusive nature of the protocol with which I was forced to comply.

While the new Commissioner of Corrections contemplates her core values (i.e., responsible, respectful, honest and caring), she may want to task someone with developing a protocol for dealing with family deaths that is less likely to cause a negative reaction from a prisoner and is more reflective of at least three of her core values.

It could hardly be considered to be coddling prisoners to implement a responsible, respectful and caring policy that would bring family out to the prison to deliver the news in person so that a prisoner is supported at his/her time of loss. A member of the Psychological Services Unit and/or a member of the prison Chaplaincy Department could easily arrange for and sit in on a private family visit and provide any intervention that might be needed under these circumstances.

\section{About the Author}

Ed Bowser has been incarcerated for more than 30 years for a crime he committed as a juvenile. A former Chairman and current member of the Board of Directors of the Lifers 'Group, Inc., Ed has been actively involved in prison reform throughout his incarceration and has earned several college degrees while in prison including a Masters degree from the Boston University Prison Education Program.

Ed can be contacted at P.O. Box 43, Norfolk, MA 02056-0043, U.S.A. 